\title{
Isolated nocturnal hypertension and subclinical target organ damage: a systematic review of the literature
}

\author{
Anne Marie O’Flynn ${ }^{1,2}$, Jamie M Madden ${ }^{1}$, Audrey J Russell ${ }^{1}$, Ronan J Curtin ${ }^{2}$ and Patricia M Kearney ${ }^{1}$ \\ Isolated nocturnal hypertension (INH) is associated with greater mortality and cardiovascular events. Subclinical target organ \\ damage (TOD) is a prognostic marker for cardiovascular events. Our objective is to systematically summarize evidence on the \\ association between INH and subclinical TOD. Observational population studies were considered. INH was defined as nighttime \\ blood pressure (BP) $\geqslant 120$ and/or $70 \mathrm{~mm} \mathrm{Hg}$ with daytime BP $<135 / 85 \mathrm{~mm} \mathrm{Hg}$. We systematically searched Pubmed, EMBASE \\ and the Cochrane Library. Abstracts were reviewed by two assessors. Potentially eligible articles were compared with inclusion \\ criteria. The search yielded 954 titles, 13 abstracts were selected for review and four articles fulfilled inclusion criteria. INH was \\ associated with higher ambulatory arterial stiffness index (0.4 unit vs. 0.35 unit, $P<0.05)$, pulse wave velocity $\left(16.2 \mathrm{~m} \mathrm{~s}^{-1} v s\right.$. \\ $\left.14.7 \mathrm{~m} \mathrm{~s}^{-1}, \boldsymbol{P}<0.05\right)$, central $(140.4 \%$ vs. $134.0 \%, P<0.05)$ and peripheral $(82.6 \%$ vs. $76.5 \%, P<0.01)$ augmentation \\ index in a Chinese study. In the same population there was no association with left ventricular hypertrophy documented by \\ electrocardiogram. INH was not associated with increased arterial stiffness or left venticular mass index in a Swedish study. \\ An American study demonstrated higher left ventricular mass $(152.46 \mathrm{~g}$ vs. $136.16 \mathrm{~g}, P=0.01$ ) and greater odds of left \\ ventricular hypertrophy (odds ratio $3.03,95 \%$ confidence interval 1.02-9.05) in unadjusted analysis. There was no association \\ with proteinuria. Evidence is inconclusive regarding the association between INH and subclinical TOD. Future research \\ should focus on trying to elucidate the mechanisms that generate INH and contribute to the higher mortality associated with \\ this BP pattern. \\ Hypertension Research (2015) 38, 570-575; doi:10.1038/hr.2015.43; published online 2 April 2015
}

Keywords: ambulatory; blood pressure; blood pressure monitoring; cardiovascular diseases; circadian rhythm; target organ damage

\section{INTRODUCTION}

Hypertension is a leading risk factor for cardiovascular disease. The World Health Organization estimates that it causes $51 \%$ of stroke deaths and $45 \%$ of coronary heart disease deaths worldwide (http:// www.who.int/gho/publications/world_health_statistics/2012/en/index. html).

Traditionally, blood pressure (BP) is measured in the office or clinic setting. Twenty-four-hour ambulatory blood pressure monitoring (ABPM) enables the BP to be recorded throughout the day and night away from the medical setting as a person carries out their usual activity. This provides more reliable assessment of BP. ${ }^{1}$ The National Institute of Health and Care Excellence in the United Kingdom now recommends $24 \mathrm{~h} \mathrm{ABPM}$ for the diagnosis of hypertension, ${ }^{2}$ whereas the JNC 7 and the recent European guidelines recommend $24 \mathrm{~h} \mathrm{ABPM}$ in certain clinical situations such as suspected white coat hypertension, drug resistance, hypotensive symptoms and others. ${ }^{1,3}$ The European guidelines also give assessment of nighttime $\mathrm{BP}$ a specific indication for ABPM.

Since the introduction of $24 \mathrm{~h}$ ABPM much has been learned regarding the diurnal BP profile. The prognostic importance of nighttime BP is recognized. ${ }^{4}$ The dipping phenomenon and nocturnal hypertension have been the focus of much research. ${ }^{5-8}$ Isolated nocturnal hypertension (INH) was first described in 2007 and describes elevated nighttime BP in the presence of normal daytime $\mathrm{BP}$, that is, a nighttime $\mathrm{BP}$ of $\geqslant 120$ and/or $70 \mathrm{~mm} \mathrm{Hg}$ with daytime BP of $<135 / 85 \mathrm{~mm} \mathrm{Hg}$ on ABPM. ${ }^{9}$ Fan et al. ${ }^{10}$ have demonstrated a higher risk of mortality and cardiovascular events in those with INH.

Subclinical target organ damage (TOD) is a prognostic marker for future cardiovascular events. ${ }^{11-14}$ It is recognized that the presence of organ damage refines cardiovascular risk assessment. ${ }^{15,16}$ It is recommended that all patients with hypertension undergo a physical examination to assess for organ damage. It can be considered an intermediate in the development of cardiovascular disease and can be detected in the heart, kidneys, brain, vasculature and retina by various methods. ${ }^{1}$

Given the greater prognostic significance of nighttime BP we postulate that those with INH have more TOD. The objective of this paper is to systematically review available evidence on the association between INH and subclinical TOD.

${ }^{1}$ Department of Epidemiology and Public Health, University College Cork, Cork, Ireland and ${ }^{2}$ Department of Cardiology, Cork University Hospital, Cork, Ireland Correspondence: Dr AM O'Flynn, Department of Epidemiology and Public Health, University College Cork, 4th Floor, Western Gateway Building, Western Road, Cork, Ireland.

E-mail: am.oflynn@ucc.ie

Received 19 June 2014; revised 15 October 2014; accepted 20 February 2015; published online 2 April 2015 


\section{METHODS}

Inclusion criteria

Study type. Original observational population-based research studies.

Study population. Those recruited to population-based observational studies undergoing $24 \mathrm{~h} \mathrm{ABPM}$ and an assessment of any target organ.

Definition of INH. Elevated nighttime BP $\geqslant 120$ and/or $70 \mathrm{~mm} \mathrm{Hg}$ and normal daytime BP $(<135 / 85 \mathrm{~mm} \mathrm{Hg})$ measured by ABPM.

Comparison group. Those with INH compared with a normotensive group.

Subclinical TOD. Recognized markers of subclinical damage in any target organ.

\section{Search methods}

We developed the search strategy for PubMed and adapted it for use in the other databases. We systematically searched Pubmed, EMBASE and the Cochrane Library. The following search terms were used as keywords and/or MESH terms: (( ((isolated OR masked) AND (nocturnal OR night-time OR nighttime OR night time) AND hypertension)) OR (((Hypertension) AND 'Blood Pressure Monitoring, Ambulatory') AND 'Circadian Rhythm'))) AND

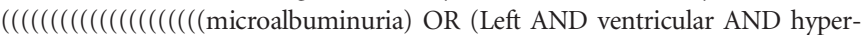
trophy)) OR (Left AND ventricular AND mass)) OR electrocardio*) OR echocardio*) OR (arterial AND stiffness)) OR (augmentation AND index)) OR (Pulse AND wave AND velocity)) OR (carotid AND ultrasound)) OR (carotid AND intima AND media AND thickness)) OR CIMT) OR (asymptomatic AND carotid AND stenosis)) OR (ankle AND brachial AND index)) OR (flow AND mediated AND dila*)) OR (endothelial AND dysfunction)) OR $(((((($ magnetic AND resonance AND imaging $))$ OR (computed AND tomography)) OR MRI) OR CT)) AND (((white AND matter AND hyperintensities)) OR (white AND matter AND lesions)))) OR retinopathy) OR (retinal AND photography)) OR (Coronary AND calcium AND score))) OR ((end OR target) AND organ AND (damage OR disease))).

Potentially relevant articles were identified. Duplicates were removed. Two independent reviewers reviewed selected abstracts and the full text of relevant papers was obtained (see Supplementary Data Appendix 1). These were compared against the inclusion criteria and assessed for quality using guidelines recommended by Hayden et al..$^{17}$ for quality appraisal in systematic reviews of prognostic studies (Table 1). The references of relevant articles were searched for further potential studies.

There was one non-English article included. The authors were contacted for an English translation that wasn't available. The article was translated with an online translation program and this was checked with a native speaker.

Because of heterogeneity in the outcomes assessed, pooling of results or meta-analysis was not carried out.

\section{RESULTS}

Figure 1 demonstrates the results of the literature search. The electronic search yielded 954 titles. On screening the titles 18 were considered potentially relevant. Duplicates were removed and 13 abstracts were selected for review. Of these five were excluded and the full text of eight articles was obtained. A further four were excluded at this point. One was a duplicate study, one was a review article and two didn't assess INH.

Four studies are included in this narrative review. The design of these are summarized in Table 2. No single measure of subclinical TOD was assessed by all four studies. The number of patients with INH in each study varied from 15 to 81 (Table 3 ).

Li et al. ${ }^{9}$ first described INH in 2007. They studied a populationbased sample from rural China. Of 677 participants, 74 (10.9\%) had INH. They excluded patients who had either a normal daytime or nighttime BP and were also on antihypertensive medications, as they couldn't ascertain what category they would have fitted into in the untreated condition.

They assessed arterial properties using radial and central augmentation indices, ambulatory arterial stiffness index and brachial-ankle pulse wave velocity. They found that all markers of arterial stiffness were significantly higher in those with INH compared with those who

Table 1 Quality assessment of included studies

\begin{tabular}{|c|c|c|c|c|}
\hline Author & Li et al. & Lu et al. & Wijkman et al. & $\begin{array}{l}\text { Ogedegbe } \\
\text { et al. }\end{array}$ \\
\hline \multicolumn{5}{|l|}{ Study participation } \\
\hline $\begin{array}{l}\text { The study sample represents the population of interest on key } \\
\text { characteristics, sufficient to limit potential bias to the results. }\end{array}$ & Yes & Yes & $\begin{array}{l}\text { Partly } \\
\text { Isolated nocturnal hypertension study sam- } \\
\text { ple characteristics not adequately described }\end{array}$ & Yes \\
\hline \multicolumn{5}{|l|}{ Study attrition } \\
\hline $\begin{array}{l}\text { Loss to follow-up (from sample to study population) } \\
\text { is not associated with key characteristics } \\
\text { (that is, the study data adequately represent } \\
\text { the sample), sufficient to limit potential bias }\end{array}$ & $\begin{array}{l}\text { Partly } \\
\text { No description of charac- } \\
\text { teristics of non- } \\
\text { responders }\end{array}$ & $\begin{array}{l}\text { Partly } \\
\text { No information on } \\
\text { response rate and } \\
\text { non-responders }\end{array}$ & $\begin{array}{l}\text { Partly } \\
\text { No information on response } \\
\text { rate and non-responders }\end{array}$ & Yes \\
\hline \multicolumn{5}{|l|}{ Prognostic factor measurement/outcome measurement } \\
\hline $\begin{array}{l}\text { The prognostic factor of interest is adequately measured } \\
\text { in study participants to sufficiently limit potential bias }\end{array}$ & Yes & Yes & Yes & Yes \\
\hline \multicolumn{5}{|l|}{ Confounding measurement and account } \\
\hline $\begin{array}{l}\text { Important potential confounders are appropriately accounted } \\
\text { for limiting potential bias with respect to the prognostic } \\
\text { factor of interest }\end{array}$ & Partly & Partly & No & Yes \\
\hline \multicolumn{5}{|l|}{ Analysis } \\
\hline $\begin{array}{l}\text { The statistical analysis is appropriate for the design of the } \\
\text { study, limiting potential for presentation of invalid results }\end{array}$ & Yes & Yes & Yes & Yes \\
\hline
\end{tabular}


Electronic database search: $\mathrm{n}=954$

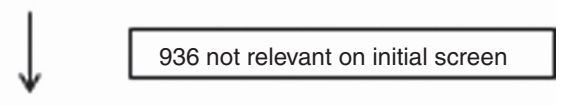

Potentially relevant: $n=18$

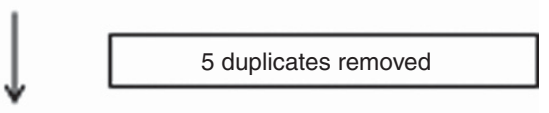

Abstracts selected for review: $n=13$

5 excluded

1 didn't assess isolated nocturnal hypertension

1 assessed hard clinical endpoints

3 conference abstracts

- 1 duplicate analysis

- 1 no normotensive comparison group

- 1 didn't assess isolated nocturnal hypertension

Full text articles assessed for eligibility: $n=8$

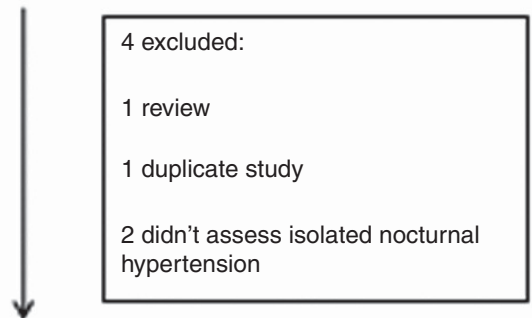

Articles included in narrative synthesis: $n=4$

Figure 1 Flow chart of the literature search.

were normotensive with adjustments applied for sex, age, height and pulse rate (Table 3 ).

$\mathrm{Lu}$ et al. ${ }^{18}$ examined the relationship between INH and left ventricular hypertrophy documented by ECG in the same Chinese population. They used Sokolow-Lyon voltage and Cornell product criteria to define left ventricular hypertrophy.

They found that those with INH had higher Sokolow-Lyon voltage and Cornell product compared with normotensive participants. However, following adjustment for sex, age, BMI, alcohol, smoking status, cholesterol, fasting glucose and antihypertensive medications these findings were no longer statistically significant. The prevalence of left ventricular hypertrophy by cutoffs was not statistically different between those with INH and normotension $(23.6 \%$ vs. $17.4 \%$, $P=0.24)$ (Table 3).
Wijkman et al. ${ }^{19}$ examined INH in middle-aged people with type 2 diabetes from 15 different primary healthcare centers in Sweden. They defined INH as clinic BP $<130 / 80$, daytime ABPM $\mathrm{BP}<135 / 85$ and nighttime ABPM BP $\geqslant 120 / 70$. Of a total sample of $414,15(3.6 \%)$ patients fulfilled this definition. They assessed arterial properties by measuring the central augmentation index and pulse wave velocity. Left ventricular mass index was determined by echocardiography.

They found no statistical difference in central pulse pressure, central augmentation index or aortic pulse wave velocity. Similarly, there was no statistically significant difference in left ventricular mass index between the isolated nocturnal hypertensive group and the normotensive group (Table 3 ).

Ogedegbe et al. ${ }^{20}$ examined INH in an African-American sample of the Jackson Study. The sample size was 425, and 81 (19.1\%) had INH. The authors excluded those on antihypertensive therapy. Two dimensional and m-mode echocardiography was carried out and left ventricular mass and mass index calculated. Spot urinary albumin: creatinine ratio was used to document proteinuria.

They found higher left ventricular mass in those with INH in unadjusted models and in models adjusted for age and gender. This was not seen in fully adjusted models, which included diabetes, cholesterol, metabolic syndrome, urinary sodium:creatinine ratio, daytime pulse pressure and alcohol. The odds ratio for left ventricular mass index $\geqslant 51 \mathrm{~g} \mathrm{~m}^{-2}$ was greater in unadjusted models for the INH group (3.03, 95\% confidence interval 1.02-9.05). However, the adjusted models were not statistically significant $(2.58,95 \%$ confidence interval $0.75-8.94)$. This was the only study to examine proteinuria. There was no increased risk of proteinuria in those with INH in either unadjusted or adjusted analysis (Table 3).

\section{DISCUSSION}

There is relatively little literature regarding the association of INH with subclinical TOD. Available evidence is inconclusive on this subject. Just four papers satisfied the inclusion criteria. No single measure of TOD was assessed by all of these. The studies included were crosssectional in design and each had some weaknesses, which further limits the capacity to draw inference.

The Li et al. study from China suggests an association with increased arterial stiffness but the issue of residual confounding remains in this study. They did not adjust for potential important confounders such as diabetes and renal disease. This isn't addressed and is a potential source of bias. They do discuss other potential limitations such as the reproducibility of INH and the use of short fixed-time intervals rather than diary intervals to analyze the ABPM results.

On the other hand, Lu et al. didn't find any increased risk of left ventricular hypertrophy documented by ECG in the same population. They do adjust for confounders, but diabetes and renal disease are omitted. They discuss the limited reproducibility of nighttime BP and also acknowledge the limited sensitivity and specificity of the ECG. However, despite the recognized weaknesses of the $\mathrm{ECG},{ }^{21}$ it is a cheap investigation, which is readily available to most practitioners and is a recognized independent predictor of prognosis, ${ }^{12,22}$ which makes it important to consider in research questions.

The Wikjman et al. study found the markers of arterial stiffness to be no different from those in the normotensive group. The small numbers included in this analysis limits interpretation. Also, limited information is provided on the study sample. We contacted the study authors for this information but this was unavailable. 
Table 2 Design of included studies

\begin{tabular}{|c|c|c|c|c|c|c|c|}
\hline $\begin{array}{l}\text { Author, } \\
\text { publication } \\
\text { date }\end{array}$ & Setting & Participants & $\begin{array}{l}\text { Study } \\
\text { design }\end{array}$ & Sampling & Cases excluded & $\begin{array}{l}\text { Subclinical } \\
\text { cardiovascular } \\
\text { disease measure }\end{array}$ & Confounders \\
\hline Li et al. ${ }^{9}$ & $\begin{array}{l}14 \text { villages in the } \\
\text { JingNing county, a } \\
\text { rural area } \sim 500 \mathrm{~km} \\
\text { south of Shanghai, } \\
\text { China }\end{array}$ & $\begin{array}{l}\text { Population- } \\
\text { based partici- } \\
\text { pants aged > } 12 \\
\text { years }\end{array}$ & $\begin{array}{l}\text { Cross- } \\
\text { sectional }\end{array}$ & $\begin{array}{l}2059 \text { villagers invited to par- } \\
\text { ticipate } \\
1490(72.4 \%) \text { gave informed } \\
\text { consent } \\
733(49 \%) \text { underwent ABPM }\end{array}$ & $\begin{array}{l}17 \text { excluded due to } \\
\text { lack of valid ABPM } \\
\text { readings } \\
14 \text { excluded due to } \\
\text { lack of measurement } \\
\text { of arterial properties } \\
25 \text { excluded with } \\
\text { either a normal day- } \\
\text { time or nighttime BP } \\
\text { on antihypertensive } \\
\text { treatment }\end{array}$ & $\begin{array}{l}\text { Central and per- } \\
\text { ipheral augmen- } \\
\text { tation index } \\
\text { Ambulatory arter- } \\
\text { ial stiffness index } \\
\text { Pulse wave } \\
\text { velocity }\end{array}$ & $\begin{array}{l}\text { Sex, age, body height and } \\
\text { pulse rate }\end{array}$ \\
\hline Lu et al. ${ }^{18}$ & $\begin{array}{l}14 \text { villages in the } \\
\text { JingNing county, a } \\
\text { rural area } \sim 500 \mathrm{~km} \\
\text { south of Shanghai, } \\
\text { China }\end{array}$ & $\begin{array}{l}\text { Population- } \\
\text { based partici- } \\
\text { pants aged > }>12 \\
\text { years }\end{array}$ & $\begin{array}{l}\text { Cross- } \\
\text { sectional }\end{array}$ & $\begin{array}{l}\text { Total numbers screened } \\
\text { not stated } \\
697 \text { underwent ABPM }\end{array}$ & $\begin{array}{l}8 \text { under } 18 \text { years } \\
\text { excluded } \\
17 \text { excluded due to } \\
\text { lack of valid ABPM } \\
\text { readings } \\
25 \text { excluded with } \\
\text { either a normal day- } \\
\text { time or nighttime BP } \\
\text { on antihypertensive } \\
\text { treatment }\end{array}$ & $\begin{array}{l}\text { Sokolow-Lyon } \\
\text { and Cornell Pro- } \\
\text { duct LVH criteria } \\
\text { on } 12 \text { lead ECG }\end{array}$ & $\begin{array}{l}\text { Sex, age, BMI, alcohol, } \\
\text { smoking status, cholesterol, } \\
\text { fasting glucose and antihy- } \\
\text { pertensive medications }\end{array}$ \\
\hline $\begin{array}{l}\text { Wijkman } \\
\text { et al. }{ }^{19}\end{array}$ & $\begin{array}{l}15 \text { different primary } \\
\text { healthcare centers in } \\
\text { the counties of Öster- } \\
\text { götland and Jönköping, } \\
\text { Sweden }\end{array}$ & $\begin{array}{l}\text { Patients with } \\
\text { type } 2 \text { diabetes } \\
\text { aged } 55-65 \\
\text { years }\end{array}$ & $\begin{array}{l}\text { Cross- } \\
\text { sectional }\end{array}$ & $\begin{array}{l}\text { Participants in the Cardio- } \\
\text { vascular Risk factors in } \\
\text { Patients with Diabetes-a } \\
\text { Prospective study in Primary } \\
\text { care (CARDIPP) } \\
\text { Total numbers screened not } \\
\text { stated } \\
414 \text { underwent ABPM }\end{array}$ & $\begin{array}{l}314 \text { excluded with } \\
\text { clinic } B P \geqslant 130 / 80 \\
25 \text { excluded due to } \\
\text { elevated daytime ABP }\end{array}$ & $\begin{array}{l}\text { Central pulse } \\
\text { pressure } \\
\text { Central augmen- } \\
\text { tation index } \\
\text { Pulse wave velo- } \\
\text { city } \\
\text { LVMI by echo- } \\
\text { cardiography }\end{array}$ & $\begin{array}{l}\text { No adjustment for } \\
\text { confounders }\end{array}$ \\
\hline $\begin{array}{l}\text { Ogedegbe } \\
\text { et al. }{ }^{20}\end{array}$ & Jackson, MS, USA & $\begin{array}{l}\text { Non- } \\
\text { institutionalised } \\
\text { African-Ameri- } \\
\text { can adults aged } \\
21-94 \text { years }\end{array}$ & $\begin{array}{l}\text { Cross- } \\
\text { sectional }\end{array}$ & $\begin{array}{l}\text { Participants of the Jackson } \\
\text { Heart Study were invited to } \\
\text { undergo } 24 \mathrm{~h} \text { ABPM } \\
5301 \text { invited to participate } \\
1150(21.6 \%) \text { agreed }\end{array}$ & $\begin{array}{l}327 \text { due to lack of } \\
\text { valid ABPM readings } \\
398 \text { excluded due to } \\
\text { antihypertensive use }\end{array}$ & $\begin{array}{l}\text { LV mass and } \\
\text { LVMI by echo- } \\
\text { cardiography } \\
\text { Urinary albumin: } \\
\text { creatinine ratio } \\
>30 \mathrm{mmol} \mathrm{dl}^{-1}\end{array}$ & $\begin{array}{l}\text { Age, gender, diabetes, cho- } \\
\text { lesterol, metabolic syndrome, } \\
\text { urinary sodium:creatinine } \\
\text { ratio, daytime pulse pressure } \\
\text { and alcohol }\end{array}$ \\
\hline
\end{tabular}

Abbreviations: ABPM, ambulatory blood pressure monitoring; BMI, body mass index; BP, blood pressure; INH, isolated nocturnal hypertension; LV, left ventricular; LVH, left ventricular hypertrophy; LVMI, left ventricular mass index.

The primary focus of this paper was to evaluate the impact of masked nocturnal hypertension, defined as a clinic $\mathrm{BP}<130 / 80$ and nighttime $\mathrm{BP} \geqslant 120 / 70$, on arterial stiffness and central $\mathrm{BP}$. The numbers included in the analysis for INH were small as they extended the definition for masked nocturnal hypertension to include those who had normal daytime BP on ABPM. The clinic BP is not usually included in the definition for INH. They may have had higher numbers in their analysis had they used the usual definition. As a result of the small numbers adjustment for confounding was not possible in the INH analysis.

Also, those on antihypertensive medication were not excluded, which could also have had an impact on BP categorization. This is addressed in the discussion by the authors. A number of other limitations are also considered including the use of a single ABPM recording, the potential impact of obstructive sleep apnea on nighttime BP and the influence of sleep depth which they couldn't address.

In the Ogedegbe et al. study, just $21.7 \%$ of invited Jackson Study participants agreed to undergo ABPM. The authors do address this potential source of bias and report the differences between those who did and did not undergo $24 \mathrm{~h} \mathrm{ABPM}$. They were younger (53.2 vs. 57.1 years, $P<0.01)$ and more likely to be male $(67.9 \%$ vs. $61.6 \%, P<0.01)$. They also raise the issue of the sample size, which may not have had sufficient power to detect differences between INH and normotension. The limited reproducibility of nighttime BP patterns and the fact that their results are based on one ABPM are discussed. Sleep quality and the impact of this on nighttime BP are also considered.

Generalizability of the findings of all the studies is a potential issue when the numbers in each study who actually underwent $24 \mathrm{~h} \mathrm{ABPM}$ is considered. The only study to address this is that by Ogedegbe et al. as outlined above. Li et al. do provide the numbers screened and those undergoing ABPM but fail to discuss the potential impact of this on the generalizability of their findings. Lu et al. and Wijkman et al. fail to provide the total numbers screened for inclusion in their studies and there is no discussion on the generalizability of the findings. All authors acknowledge the potential limited reproducibility of the INH pattern. Analysis in all four of the studies was based on one ABPM 
Table 3 Results of included studies

\begin{tabular}{|c|c|c|c|c|}
\hline $\begin{array}{l}\text { Author, } \\
\text { publica- } \\
\text { tion date }\end{array}$ & $\begin{array}{l}\text { Number of } \\
\text { participants } \\
\text { INH/total } \\
\text { (\% INH) }\end{array}$ & Results & & Summary of findings \\
\hline Li et al. ${ }^{9}$ & 74/677 (10.9) & $\begin{array}{l}\text { Central augmentation index } \% \\
\text { Peripheral augmentation index } \% \\
\text { Ambulatory arterial stiffness index, units } \\
\text { Brachial-ankle pulse wave velocity, } \mathrm{ms}^{-1}\end{array}$ & $\begin{array}{l}140.4 \text { vs. } 134.0, P<0.05 \\
82.6 \text { vs. } 76.5, P<0.01 \\
0.4 \text { vs. } 0.35, P<0.05 \\
16.2 \text { vs. } 14.7, P<0.05\end{array}$ & $\begin{array}{l}\text { INH group showed significant increases in } \\
\text { all four measured indices of arterial stiffness } \\
\text { compared with normotensive group }\end{array}$ \\
\hline Lu et al. ${ }^{18}$ & $72 / 647(11.1)$ & Sokolow-Lyon and Cornell Product LVH criteria & $23.6 \%$ vs. $17.4 \%, P=0.24$ & $\begin{array}{l}\text { No difference in prevalence of LVH in those } \\
\text { with INH compared with normotensives }\end{array}$ \\
\hline $\begin{array}{l}\text { Wijkman } \\
\text { et al. }{ }^{19}\end{array}$ & $15 / 414(3.6)$ & $\begin{array}{l}\text { Central pulse pressure } \\
\text { Central augmentation index } \\
\text { Aortic pulse wave velocity, } \mathrm{m} \mathrm{s}^{-1} \\
\text { LVMI }\end{array}$ & $\begin{array}{l}\text { Figures not provided } \\
\text { Figures not provided } \\
10.3 \text { vs. } 9.3, P=0.06 \\
\text { Figures not provided }\end{array}$ & $\begin{array}{l}\text { No difference in central pulse pressure, } \\
\text { central augmentation index, aortic pulse } \\
\text { wave velocity or LVMI }\end{array}$ \\
\hline & & $\begin{array}{l}\text { Unadjusted LVH (OR LVMI } \geqslant 51 \mathrm{~g} \mathrm{~m}^{-2} \text { ) } \\
\text { Age- and gender-adjusted } L V H \\
\left(\mathrm{OR} \text { LVMI } \geqslant 51 \mathrm{~g} \mathrm{~m}^{-2} \text { ) }\right. \\
\text { Multivariable adjusted LVH }\left(\mathrm{OR} \text { LVMI } \geqslant 51 \mathrm{~g} \mathrm{~m}^{-2} \text { ) }\right.\end{array}$ & $\begin{array}{l}3.03(95 \% \text { Cl } 1.02-9.05, P=0.05) \\
2.89(95 \% \text { Cl } 0.96-8.69, P=0.06) \\
2.58(95 \% \text { Cl } 0.75-8.94, P=0.13)\end{array}$ & $\begin{array}{l}\text { INH group greater odds of LVH in unad- } \\
\text { justed model }\end{array}$ \\
\hline & & $\begin{array}{l}\text { Unadjusted proteinuria (OR UACR }>30 \mathrm{mmol} \mathrm{dl}^{-1} \text { ) } \\
\text { Age- and gender-adjusted proteinuria } \\
\left(O R \text { UACR }>30 \mathrm{mmol}^{-1} \text { ) }\right. \\
\text { Multivariable adjusted proteinuria (OR } \\
\text { UACR }>30 \mathrm{mmol} \mathrm{dl}^{-1} \text { ) }\end{array}$ & $\begin{array}{l}3.34(95 \% \mathrm{Cl} 0.91-12.28, P=0.07) \\
3.29(95 \% \mathrm{Cl} 0.89-12.19, P=0.08) \\
1.95(95 \% \mathrm{Cl} 0.46-8.22, P=0.37)\end{array}$ & No increased risk of proteinuria \\
\hline
\end{tabular}

Abbreviations: BP, blood pressure; Cl, confidence interval; INH, isolated nocturnal hypertension; LV, left ventricular; LVH, left ventricular hypertrophy; LVMI, left ventricular mass index; OR, odds ratio; UACR, urinary albumin creatinine ratio.

recording. Nighttime BP patterns are not always reproducible although using absolute values rather than dipping status was found to result in more reproducible results. ${ }^{23} \mathrm{Li}$ et al. carried out a followup study on 30 participants with INH with a mean follow-up time of 3.5 years. They found that 33\% still had INH, 33\% developed daynight hypertension, whereas $27 \%$ were normotensive and $7 \%$ had isolated daytime hypertension. ${ }^{9}$

Categorising a normally distributed continuous variable such as BP impacts power to detect real associations. ${ }^{24,25}$ However, clinicians need a diagnostic reference with thresholds that define normal and abnormal when managing patients. Therefore, from a practical perspective, there are advantages to using categories. The numbers of patients with INH in the four studies were not large, which further reduces power to detect a true association.

Studies that included participants taking antihypertensive medications were not excluded from the review. Antihypertensive medications potentially influence BP categorization. Those on treatment may demonstrate INH but in the untreated state they may have demonstrated a sustained hypertension pattern. This is only really relevant for the Wikjman et al. study as the Chinese studies excluded those on medications with either a normal daytime or nighttime BP, and the Ogedegbe et al. study excluded those on medications altogether. Given the small numbers in the Wikjman et al. study this is unlikely to have had an impact on the overall findings.

The prevalence of INH is 6\% in Western Europe and $7.9 \%$ in Eastern Europe, which is significantly lower than that in Asia (10.9\% in China and $10.2 \%$ in Japan), South Africa $(10.2 \%)^{26}$ or in African Americans (19.1\%). ${ }^{20}$ The mechanisms underlying the differences in prevalence rates and the increased risk associated with INH are not clear. Documenting changes in the cardiovascular system prior to the development of clinical disease may help us to further understand these potential mechanisms. Blunted sodium metabolism, obstructive sleep apnea and reverse causality have been proposed. ${ }^{26}$ Olmesartan has been demonstrated to significantly reduce urinary albumin excretion after 16 weeks of active therapy. This was associated with a preferential fall in nocturnal BP. The authors suggest that prevention of renal tubular sodium reabsorption may be the mechanism involved. ${ }^{27}$ This study also suggests that treating nocturnal BP may improve albuminuria and perhaps other TOD but this requires further study. The outcomes assessed in this review can be considered surrogate markers. The use of surrogate markers is not without controversy. ${ }^{28,29}$ They need to accurately measure disease and predict future events, whereas measurement needs to be meticulous. ${ }^{30}$ However, the measures used in the four studies in this review all have a weight of literature behind them and are recognized as valid tools. ${ }^{30,31}$

The strengths of this review include a focused question with relative paucity of information and it identifies an evidence gap as the question isn't answered by the available literature. The inclusion of non-English articles makes it likely that all relevant studies were identified. However, as with any systematic review there is always the possibility of missed studies. 


\section{CONCLUSION}

The evidence is inconclusive with respect to the association between INH and subclinical TOD. Future research should focus on elucidating the mechanisms that generate INH and the higher mortality risk attached to it. The reproducibility of this particular BP pattern also needs to be elucidated. Specifically, research should focus on whether normalizing INH in prospective studies reduces cardiovascular events.

\section{CONFLICT OF INTEREST}

Dr Anne Marie O'Flynn is currently receiving funding from a Health Research Board Ireland research training fellowship for healthcare professionals (reference HPF/2012/14) and has also received the John Feely research bursary from the Irish Heart Foundation to support this work. She has also received payment unrelated to the submitted work through her institution for the development of the European Society of Cardiology e-learning platform. Mr Jamie Madden is receiving funding from the Health Research Board Ireland under the $\mathrm{PhD}$ Scholars Program (reference PHD/2007/16). Dr Audrey Russell is funded by the Irish College of General Practitioners Clinical Academic Fellowship in General Practice. Dr Ronan Curtin has received funding and subsistence support for lectures and activities outside of the submitted work from A Menarini, Daichi Sankyo, Astra Zeneca, Bayer, Bristol Myers Squibb, Pfizer and Servier pharmaceutical companies. Prof Patricia Kearney has received grants from the Health Research Board Ireland and the European Union FP7 for work outside of the submitted work.

\section{ACKNOWLEDGEMENTS}

The authors wish to acknowledge and thank Professor John Browne of the Department of Epidemiology and Public Health, University College Cork who teaches module PG7016 'Systematic Reviews for the Health Sciences'. This module was completed by AM O'Flynn and J Madden.

1 Mancia G, Fagard R, Narkiewicz K, Redon J, Zanchetti A, Böhm M, Christiaens T, Cifkova R, De Backer G, Dominiczak A, Galderisi M, Grobbee DE, Jaarsma T, Kirchhof $P$, Kjeldsen SE, Laurent S, Manolis AJ, Nilsson PM, Ruilope LM, Schmieder RE, Sirnes PA, Sleight P, Viigimaa M, Waeber B, Zannad F, Redon J, Dominiczak A, Narkiewicz K, Nilsson PM, Burnier M, Viigimaa M, Ambrosioni E, Caufield M, Coca A, Olsen MH, Schmieder RE, Tsioufis $\mathrm{C}$, van de Borne $\mathrm{P}$, Zamorano JL, Achenbach S, Baumgartner $\mathrm{H}$, Bax JJ, Bueno H, Dean V, Deaton C, Erol C, Fagard R, Ferrari R, Hasdai D, Hoes AW, Kirchhof P, Knuuti J, Kolh P, Lancellotti P, Linhart A, Nihoyannopoulos P, Piepoli MF, Ponikowski P, Sirnes PA, Tamargo JL, Tendera M, Torbicki A, Wijns W, Windecker S, Clement DL, Coca A, Gillebert TC, Tendera M, Rosei EA, Ambrosioni E, Anker SD, Bauersachs J, Hitij JB, Caulfield M, De Buyzere M, De Geest S, Derumeaux GA, Erdine S, Farsang C, Funck-Brentano C, Gerc V, Germano G, Gielen S, Haller H, Hoes AW, Jordan J, Kahan T, Komajda M, Lovic D, Mahrholdt H, Olsen MH, Ostergren J, Parati G, Perk J, Polonia J, Popescu BA, Reiner Z, Rydén L, Sirenko Y, Stanton A, Struijker-Boudier H, Tsioufis C, van de Borne P, Vlachopoulos C, Volpe M, Wood DA. 2013 ESH/ESC Guidelines for the management of arterial hypertension: the Task Force for the management of arterial hypertension of the European Society of Hypertension (ESH) and of the European Society of Cardiology (ESC). Eur Heart J 2013; 34: 2159-2219.

2 http://www.nice.org.uk/guidance/CG127. National Institute for Health and Care Excellence 2011.

3 Chobanian AV, Bakris GL, Black HR, Cushman WC, Green LA, Izzo JL Jr, Jones DW, Materson BJ, Oparil S, Wright JT Jr, Roccella EJ. Joint national committee on prevention, detection, evaluation, and treatment of high blood pressure. national heart, lung, and blood institute; national high blood pressure education program coordinating committee. seventh report of the joint national committee on prevention, detection, evaluation, and treatment of high blood pressure. Hypertension 2003; 42: 1206-1252.

4 Hansen TW, Li Y, Boggia J, Thijs L, Richart T, Staessen JA. Predictive role of the nighttime blood pressure. Hypertension 2011; 57: 3-10.

5 de la Sierra A, Redon J, Banegas JR, Segura J, Parati G, Gorostidi M, de la Cruz JJ, Sobrino J, Llisterri JL, Alonso J, Vinyoles E, Pallarés V, Sarría A, Aranda P, Ruilope LM. Spanish Society of Hypertension Ambulatory Blood Pressure Monitoring Registry Investigators. Prevalence and factors associated with circadian blood pressure patterns in hypertensive patients. Hypertension 2009; 53: 466-472.

6 Perez-Lloret S, Toblli JE, Cardinali DP, Malateste JC, Milei J. Nocturnal hypertension defined by fixed cut-off limits is a better predictor of left ventricular hypertrophy than non-dipping. Int J Cardiol 2008; 127: 387-389.
7 Tsioufis C, Andrikou I, Thomopoulos C, Petras D, Manolis A, Stefanadis C. Comparative prognostic role of nighttime blood pressure and nondipping profile on renal outcomes. Am J Nephrol 2011; 33: 277-288.

8 Tsioufis C, Andrikou I, Thomopoulos C, Syrseloudis D, Stergiou G, Stefanadis C. Increased nighttime blood pressure or nondipping profile for prediction of cardiovascular outcomes. J Hum Hypertens 2010; 25: 281-293.

9 Li Y, Staessen JA, Lu L, Li L-H, Wang G-L, Wang J-G. Is isolated nocturnal hypertension a novel clinical entity? Findings from a Chinese population study. Hypertension 2007; 50: 333-339.

10 Fan HQ, Li Y, Thijs L, Hansen TW, Boggia J, Kikuya M, Björklund-Bodegård $K$, Richart T, Ohkubo T, Jeppesen J, Torp-Pedersen C, Dolan E, Kuznetsova T, Stolarz-Skrzypek K, Tikhonoff V, Malyutina S, Casiglia E, Nikitin Y, Lind L, Sandoya E, Kawecka-Jaszcz K, Imai Y, Ibsen H, O'Brien E, Wang J, Staessen JA. International Database on Ambulatory Blood Pressure In Relation to Cardiovascular Outcomes Investigators. Prognostic value of isolated nocturnal hypertension on ambulatory measurement in 8711 individuals from 10 populations. J Hyperten 2010; 28: 2036-2045.

11 Chronic Kidney Disease Prognosis Consortium, Matsushita K, van der Velde M, Astor BC, Woodward M, Levey AS, de Jong PE, Coresh J, Gansevoort RT. Association of estimated glomerular filtration rate and albuminuria with all-cause and cardiovascular mortality in general population cohorts: a collaborative meta-analysis. Lancet 2010; 375: 2073-2081.

12 Levy D, Salomon M, D'Agostino RB, Belanger AJ, Kannel WB. Prognostic implications of baseline electrocardiographic features and their serial changes in subjects with left ventricular hypertrophy. Circulation 1994; 90: 1786-1793.

13 Levy D, Garrison RJ, Savage DD, Kannel WB, Castelli WP. Prognostic implications of echocardiographically determined left ventricular mass in the Framingham Heart Study. N Engl J Med 1990; 322: 1561-1566.

14 Laurent S, Boutouyrie P, Asmar R, Gautier I, Laloux B, Guize L, Ducimetiere P, Benetos A. Aortic stiffness is an independent predictor of all-cause and cardiovascular mortality in hypertensive patients. Hypertension 2001; 37: 1236-1241.

15 Sehestedt T, Jeppesen J, Hansen TW, Wachtell K, Ibsen H, Torp-Pedersen C, Hildebrandt $\mathrm{P}$, Olsen $\mathrm{MH}$. Risk prediction is improved by adding markers of subclinical organ damage to SCORE. Eur Heart J 2010; 31: 883-891.

16 Volpe M, Battistoni A, Tocci G, Rosei EA, Catapano AL, Coppo R, del Prato S, Gentile S, Mannarino E, Novo S, Prisco D, Mancia G. Cardiovascular risk assessment beyond Systemic Coronary Risk Estimation: a role for organ damage markers. J Hypertens 2012; 30: 1056-1064.

17 Hayden JA, Cote P, Bombardier C. Evaluation of the quality of prognosis studies in systematic reviews. Ann Intern Med 2006; 144: 427-437.

$18 \mathrm{Lu} \mathrm{L}$, Li Y, Huang QF. The relationship between isolated nocturnal hypertension and left ventricular hypertrophy. Zhonghua nei ke za zhi 2008; 47: 819-822.

19 Wijkman M, Länne T, Engvall J, Lindström T, Östgren CJ, Nystrom FH. Masked nocturnal hypertension-a novel marker of risk in type 2 diabetes. Diabetologia 2009; 52: $1258-1264$

20 Ogedegbe G, Spruill TM, Sarpong DF, Agyemang C, Chaplin W, Pastva A, Martins D, Ravenell J, Pickering TG. Correlates of isolated nocturnal hypertension and target organ damage in a population-based cohort of African Americans: the Jackson Heart Study. Am J Hypertens 2013; 26: 1011-1016.

21 Levy D, Labib SB, Anderson KM, Christiansen JC, Kannel WB, Castelli WP. Determinants of sensitivity and specificity of electrocardiographic criteria for left ventricular hypertrophy. Circulation 1990; 81: 815-820.

22 Okin PM, Devereux RB, Jern S, Kjeldsen SE, Julius S, Nieminen MS, Snapinn S, Harris KE, Aurup P, Edelman JM, Wedel H, Lindholm LH, Dahlöf BLIFE Study Investigators. Regression of electrocardiographic left ventricular hypertrophy during antihypertensive treatment and the prediction of major cardiovascular events. JAMA 2004; 292: 2343-2349.

23 White WB, Larocca GM. Improving the utility of the nocturnal hypertension definition by using absolute sleep blood pressure rather than the "dipping" proportion. Am J Cardiol 2003; 92: 1439-1441.

24 Altman DG, Royston P. The cost of dichotomising continuous variables. BMJ 2006; 332: 1080.

25 Royston P, Altman DG, Sauerbrei W. Dichotomizing continuous predictors in multiple regression: a bad idea. Stat Med 2006; 25: 127-141.

$26 \mathrm{Li} \mathrm{Y}$, Wang J-G. Isolated nocturnal hypertension: a disease masked in the dark. Hypertension 2013; 61: 278-283.

27 Yanagi M, Tamura K, Fujikawa T, Wakui H, Kanaoka T, Ohsawa M, Azushima K, Maeda A, Kobori H, Umemura S. The angiotensin II type 1 receptor blocker olmesartan preferentially improves nocturnal hypertension and proteinuria in chronic kidney disease. Hypertens Res 2013; 36: 262-269.

28 Temple R. Are surrogate markers adequate to assess cardiovascular disease drugs? JAMA 1999; 282: 790-795.

29 Fleming TR, DeMets DL. Surrogate end points in clinical trials: are we being misled? Ann Intern Med 1996; 125: 605-613.

30 Mancini GBJ, Dahlöf B, Díez J. Surrogate markers for cardiovascular disease: structural markers. Circulation 2004; 109: IV22-IV30.

31 Cohn JN, Quyyumi AA, Hollenberg NK, Jamerson KA. Surrogate markers for cardiovascular disease: functional markers. Circulation 2004; 109: IV31-IV46. 